Matej RADINJA

\title{
The water-management aspect of blue-green infrastructure in cities
}

Blue-green infrastructure (BGI) consists of natural and semi-natural (hence green) decentralized systems for urban stormwater management (hence blue), which, in addition to their primary purpose, provide a variety of shared benefits and ecosystem services. With the exception of a few cities that have adopted strategies for systemic BGI implementation, its use is still sporadic, in the form of isolated best practices, and is absent from Slovenian cities. Due to established spatial planning practices, Slovenian cities have a sufficient amount of relatively evenly distributed green areas, but these are not planned according to BGI principles and therefore their potential for managing stormwater is not utilized (i.e., water-wise multifunctionality). Because urban space management and its associated elements are a multidisciplinary field, we explored the link between spatial planning and water management in international strategic documents and in Slovenian national legislation. Based on a literature review, such connections are promoted at the international level; however, they are not sufficiently integrated in national legislation. Thus, a sectoral approach to water management and urban planning still prevails in Slovenian cities. Four examples of systemic BGI implementation (Rotterdam, Copenhagen, Philadelphia, and Chinese cities) are presented here. They link spatial planning and water management in BGI design and implementation. The results of this analysis were used to develop recommendations on integrating spatial planning and water management that go beyond sectoral urban space management, aiming to facilitate BGI implementation in (Slovenian) cities.

Keywords: water management, spatial planning, urban drainage, blue-green infrastructure, climate change 


\section{Introduction}

Climate change impacts and the current trend of urban development are creating conditions that existing urban infrastructure cannot handle successfully when exposed to extreme events (e.g., extreme precipitation and heat waves; Krajnc, 2019). Climate change projections for Slovenia predict that by mid-century one can expect an increase in the number of extreme weather conditions: severe heat in summer accompanied by greater variability in temperature and precipitation, more heavy precipitation events (cloudbursts), intensification of the hydrological cycle, more frequent flooding, a significant increase in the frequency of summer droughts, and an increase in the number of days with favourable conditions for summer thunderstorms (Dolinar et al., 2014). Adapting or increasing the resilience of cities to extreme events is a complex process that requires the involvement and cooperation of all stakeholders that participate in shaping and managing urban areas (Klemen et al., 2020). In practice, stakeholders often act in professional silos and in a disconnected manner, which is increasingly emerging as one of the greatest barriers to sustainable urban water management (Globevnik \& Simoneti, 2020). This is particularly the case for novel management concepts that have recently been introduced, such as BGI. In Slovenia and globally, decision-makers have not yet established suitable planning and management approaches (Ravnikar \& Goličnik Marušić, 2019).

The key to addressing the challenges posed to cities by climate change is managing the urban water cycle, which, in addition to water infrastructure, is directly related to (un)paved urban areas and their surrounding countryside. Therefore, the spatial planning process is increasingly important for sustainable water management (Serrao-Neumann et al., 2017). The aim is to mimic as much as possible the natural surface runoff typical for the pre-development period in the area. However, new developments inherently cause more impervious areas, which require the expansion of grey infrastructure for urban drainage purposes (i.e., public utility infrastructure, PUI). In sustainable urban management and urban development, stormwater should not be treated as mere waste, directed to the sewerage system as quickly as possible. Such management acts as an environmental burden and encourages linear rather than circular and sustainable management of urban water resources. In this context, the connection between urban planning and sustainable development turns out to be of great importance for (water) resource management (Agudelo-Vera et al., 2011).

This article draws attention to urban water management, which can only be successful if the integration of all disciplines (water managers, spatial planners, urban planners, architects and landscape architects, civil engineers, geographers, sociologists, etc.) involved in BGI and PUI planning, and cross-sectoral integration at the level of urban governance are ensured. We first outline the current state of urban water management and the consequences of climate change. Then we present examples of best practices and opportunities for improving urban water management with BGI. The article also highlights the necessary connection between spatial planning and water management at the strategic and implementation levels.

\section{Method}

In line with the aim and objectives of the article, documents on the approach to water management in Slovenian cities were comparatively analysed. We covered documents at the international and national (Slovenian) levels in spatial planning and water management. We then examined selected examples of best practices that demonstrate how suitable planning and spatialization of BGI address existing problems (e.g., flooding, pollution of waterbodies, and urban heat islands) and at the same time create space that provides additional ecosystem services (e.g., promoting biodiversity, reducing pollution, and mitigating urban heat islands). The results of the two analyses were then compared and presented. Recommendations are given for more integrated cross-sectoral coordinated water management in Slovenian cities.

\section{The urban water cycle and blue-green infrastructure}

\subsection{Development of the urban water cycle}

The spread of urban areas and urbanization increase the share of impermeable surfaces and leads to changes in the natural water cycle, especially when traditional urban drainage (i.e., the use of grey infrastructure) is used (Bacchin et al., 2014). These changes are reflected in reduced infiltration and evapotranspiration, and in increased surface runoff (Butler et al., 2018). Hence, the local water cycle is influenced by the history of urban development and previous urban water-management approaches. These approaches were shaped by the expectations of society (i.e., cumulative socio-political drivers) and the development of new approaches and technologies that various disciplines used to address emerging social problems (e.g., diseases such as cholera and typhoid, drinking water shortages, and floods). Panjan (2005) summarized the development of sanitary engineering, which deals with the management of water in cities to protect human health, from ancient times to 2000 . It is mainly characterized by three water services: water supply, wastewater treatment, and urban flood protection. However, 
Table 1: The development of urban water management.

\begin{tabular}{llll}
\hline Phase & Water-management approach & Cumulative socio-political drivers & Service delivery functions \\
\hline 1 & Water-supply city & Water-supply access and security & Supply hydraulics \\
\hline 3 & Sewered city & Public health protection & Separate sewerage schemes \\
\hline 4 & Drained city & Flood protection & Drainage, channelization \\
\hline 5 & Waterway city & $\begin{array}{l}\text { Social amenity, environmental } \\
\text { protection }\end{array}$ & Point and diffuse source pollution management \\
\hline 6 & Water-cycle city & Limits on natural resources & $\begin{array}{l}\text { Diverse fit-for-purpose sources and conservation, } \\
\text { promoting waterway protection }\end{array}$ \\
\hline
\end{tabular}

with improving socio-economic conditions, environmental awareness, and imminent climate change impacts, awareness in society is growing that such linear systems place external pressure on the environment and are unsustainable. Therefore, the European Water Framework Directive (Directive 2000/60 /EC of the European Parliament and of the Council of $23 \mathrm{Oc}$ tober 2000 Establishing a Framework for Community Action in the Field of Water Policy, 2000) and Slovenian Water Act (Sln. Zakon o vodah, 2002) set limits and a regulatory framework for achieving good ecological and chemical status of water bodies. However, the adopted regulatory framework is still based on upgrading existing linear systems (i.e., construction of wastewater treatment plants) and does not yet follow modern concepts of water management based on approaches typical for the circular economy: closure of material flows, reuse, recovery of natural resources, use of resources that are fit for purpose, and so on. Considering the emerging changes, Brown et al. (2009) divided the historical development of existing and proposed urban water-management concepts into six phases, with the target being a water-sensitive city (Table 1). In general, most Slovenian and European cities are in the fourth phase (i.e., a waterway city), encompassing the previous phases, which provide water supply, wastewater treatment, and flood protection. Furthermore, some of the water services typical for the fifth and sixth phases are partially included.

The fourth phase, called a waterway city, focuses on the quality of water bodies in cities and their integration into urban life because they offer many benefits (e.g., recreational and leisure opportunities, amenity, and formation of a green urban system), which contribute to improving public health. Although water quality has improved significantly in recent decades, mainly due to the end of industrial production and the construction of industrial and municipal wastewater treatment plants, diffuse and point sources of pollution still pose a threat. Typical representatives of uncontrolled point source pollution are combined sewerage overflows. Diffuse sources of pollution cannot be controlled by centralized systems and require the introduction of decentralized approaches and technologies. Consequently, the current business model of urban water management needs to be upgraded, including its financing and the transfer of responsibilities.

The fifth phase, the water-circle city, is based on the recognition that water resources are limited in quantity and quality. It therefore recognizes the use of lower-quality water resources (i.e., alternative water sources, such as rainwater, stormwater, and sanitary wastewater) to meet needs that do not require drinking water. Because water is a medium that transfers nutrients, minerals, and energy, this phase also addresses their extraction from wastewater, which consequently becomes a new resource. This approach also requires the involvement of other sectors (e.g., agriculture, food, and energy) and the adaptation of their infrastructure.

The sixth phase is the water-sensitive city. The main driver for development of these cities is climate change impacts and the desire to make cities as resilient as possible, as well as the intergenerational transfer of the value of water (i.e., preserving the quantity and quality of water resources for future generations). Although this phase represents a type of governance, it is primarily a vision of community development and its sustainable attitude toward the environment and space. It is characterized by the diversity and adaptability of technologies, infrastructure, and land use in cities designed to promote sustainable practices and social capital. The link between society and technologies plays an important role. In such a context, the relationship between the water sector and society (i.e., the social contract) would be constantly changing and would require an adaptable and flexible institutional framework.

With each successive phase, urban water management demands involvement of an increasing number of sectors because all natural elements (water, soil, air, and living beings) are interconnected. Although this is well understood in general, the holistic approach toward the management of natural resources 
has been lost by its division into subsystems based on individual disciplines. Therefore, integration and cooperation with other disciplines that work in urban development is urgently needed to implement new holistic approaches for water management. Such integration is already establishing itself in some places with new approaches to urban development planning (Hung et al., 2012). These are no longer simply searching for technological solutions but are increasingly moving toward closing the loop in the urban water cycle by using BGI (Bacchin et al., 2014). This is because green infrastructure adds value to public open spaces and their contribution to urban ecosystem services, and blue infrastructure manages stormwater. However, when they are combined, they can provide significantly more complex benefits in contemporary urban planning. Recognising BGI as an interdisciplinary approach for urban planning is therefore crucial for understanding and implementing it in spatial planning practice.

\subsection{Blue-green infrastructure}

Blue-green infrastructure can be defined as natural and semi-natural (hence green) decentralized systems designed to manage urban stormwater (hence blue), while providing a wide range of ecosystem services (Liao et al., 2017; Lamond \& Everett, 2019). Its basic philosophy is to mimic natural hydrological processes (i.e., retention, infiltration, and evap$o$ (transpi)ration) with the aim of managing rainwater locally to prevent generation of runoff and mixing with wastewater. A standard term for these measures has not yet been established in Slovenia or globally. There are a number of related terms and concepts in English that are largely based on similar processes and technologies. For example, in the UK, the most commonly used term is sustainable urban drainage systems (SUDS; Woods Ballard et al.). In the US, the terms used are low-impact development (LID), best management practice (BMP), and stormwater control measures (SCM), and in Australia the term used is water-sensitive urban design (WSUD; Fletcher et al., 2015). They differ primarily in the scale, such as a single property, a street, a neighbourhood, a district, a city, or even larger regional systems. Recently, the term nature-based solutions (NBS) has also become widely used, encompassing a variety of technologies that mimic or are based on natural processes and are cost-effective, while providing environmental, social, and economic benefits while enhancing resilience (Langergraber et al., 2020). These solutions bring more nature and natural features and processes into cities and landscapes through systemic interventions that are locally appropriate and resource-efficient (European Commission, 2020). We would like to emphasize that these concepts are largely based on the same technologies and have the same objectives, but, because they were developed simultaneously in different parts of the world and within different disciplines, they are named differ- ently. Based on the definitions presented, it is clear that BGI should be understood much more broadly and not merely as a water-management approach. Namely, it offers improvements not only in water management, but also in many other areas, such as climate change, agriculture, forestry, urban planning, nature conservation, disaster prevention, and even regional development. It is therefore a highly interdisciplinary approach that has not yet been fully implemented in Slovenian practice. Elements of BGI in urban space are mostly part of green areas and thus, in the spatial planning context, they form part of the green system of a settlement or green infrastructure as introduced by the Spatial Development Strategy of Slovenia by 2050 (Sln. Strategija prostorskega razvoja Slovenije 2050; Ministrstvo za okolje in prostor, 2020a).

In other countries, with few exceptions such as the UK and the Netherlands, the additional benefits of BGI have not yet been sufficiently communicated to national and local authorities, PUI managers, spatial planners, and the public. Unlike the traditional approach based on drainage and retention of water in the sewerage system, decision-making guidelines and software tools do not yet exist for such systems. As a result, the shared benefits of BGI may be overlooked because the processes for assessing different solution scenarios are unclear and the longterm operation of these systems is subject to uncertainty or risk for stakeholders. Although some modelling tools already include modules for modelling BGI from hydraulic and water-quality perspectives, the shared benefits, such as amenity, biodiversity, and long-term cost-benefit aspects, are poorly included in these tools (Chow et al., 2014). However, certain software tools, such as $\mathrm{E}^{2}$ STORMED (Morales-Torres et al., 2016) allow a comprehensive assessment of individual measures with all their benefits but use simpler hydrological-hydraulic models, and therefore the use of results from more complex models for appropriate treatment is recommended (Radinja et al., 2019).

Figure 1 presents the elements of BGI according to their primary purpose: reducing surface runoff, reducing peak flows, or improving water quality. At the same time, it shows which processes (e.g., retention, infiltration, and evapotranspiration) contribute to the achievement of these purposes and to what extent. Moreover, the shared benefits (i.e., ecosystem services) provided by the elements are indicated.

\section{An integrated approach to urban water management}

International and national strategic documents that guide the development of a particular field are very important for implementing new concepts and practices. This article explores 


\begin{tabular}{|c|c|c|c|c|c|c|c|c|c|c|c|c|c|c|c|}
\hline \multirow{3}{*}{\multicolumn{3}{|c|}{$\begin{array}{l}\emptyset \text { Primary function } \\
\checkmark \text { Secondary function } \\
\text { \& Incidental } \\
\text { + Additional benefit }\end{array}$}} & \multirow{2}{*}{\multicolumn{7}{|c|}{ Runoff reduction }} & \multirow{2}{*}{\multicolumn{2}{|c|}{ Peak flow reduction }} & \multicolumn{4}{|c|}{ Improved water quality } \\
\hline & & & & & & & & & & & & \multicolumn{2}{|c|}{ Biological treatment } & \multicolumn{2}{|c|}{ Pfiysical nitration } \\
\hline & & & \multirow{2}{*}{$\frac{\begin{array}{c}\text { Rain } \\
\text { gardén }\end{array}}{\square}$} & \multirow{2}{*}{$\begin{array}{c}\begin{array}{c}\text { Rairwater } \\
\text { harvesting }\end{array} \\
\square\end{array}$} & \multirow{2}{*}{$\frac{\begin{array}{c}\text { Permeab! } \\
\text { e pavini }\end{array}}{\square}$} & \multirow{2}{*}{$\frac{\begin{array}{c}\text { Green } \\
\text { roof }\end{array}}{\square}$} & \multirow{2}{*}{$\frac{\text { Trees }}{0}$} & \multirow{2}{*}{$\begin{array}{c}\begin{array}{c}\text { Bioretention } \\
\text { cell }\end{array} \\
\square\end{array}$} & \multirow{2}{*}{$\begin{array}{c}\begin{array}{c}\text { Infiltration } \\
\text { structure }\end{array} \\
\square\end{array}$} & \multirow{2}{*}{\begin{tabular}{|c}
$\begin{array}{c}\text { Detention } \\
\text { basins }\end{array}$ \\
$\%$
\end{tabular}} & \multirow{2}{*}{$\frac{\text { Ponds }}{r}$} & Constructed & Swales & Sand liter & Fitrer \\
\hline \multirow{9}{*}{ 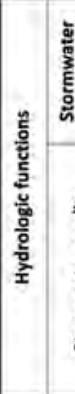 } & & Retention & & & & & & & & & & $\%$ & $\%$ & 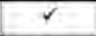 & $r$ \\
\hline & \multirow{3}{*}{ 密 } & Infiltration & 甲 & $\%$ & 匹 & & $\checkmark$ & $\emptyset$ & 口 & $*$ & $*$ & $*$ & $\%$ & $\checkmark$ & $\checkmark$ \\
\hline & & Detention & $r$ & & & $\checkmark$ & $\checkmark$ & $\checkmark$ & 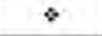 & $\emptyset$ & $\checkmark$ & $*$ & $\checkmark$ & & $r$ \\
\hline & & Evapotranspiration & $r$ & $*$ & & 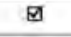 & $\square$ & 口 & & $r$ & $\%$ & 四 & 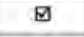 & $*$ & 8 \\
\hline & \multirow{5}{*}{ 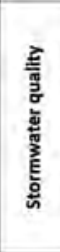 } & Sedimentation & 曰 & $*$ & $r$ & & & $r$ & & 曰 & $\emptyset$ & 回 & $\emptyset$ & 曰 & 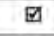 \\
\hline & & Filtration & 曰 & $*$ & $\emptyset$ & $\emptyset$ & $*$ & $\checkmark$ & & $*$ & & 甲 & $\checkmark$ & 回 & 曰 \\
\hline & & Straining & $\checkmark$ & $*$ & & & & 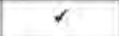 & & $*$ & & $\square$ & $\emptyset$ & & $\square$ \\
\hline & & $\begin{array}{l}\text { Extended treatment } \\
\text { (chernical) }\end{array}$ & r & & & $*$ & & & & $*$ & $*$ & 四 & $r$ & $\checkmark$ & \\
\hline & & $\begin{array}{l}\text { Extended treatment } \\
\text { (biological) }\end{array}$ & 曰 & & & 可 & $\varpi$ & $\checkmark$ & & $\%$ & $\%$ & $\varpi$ & 凶 & 曰 & $\%$ \\
\hline \multirow{6}{*}{\multicolumn{2}{|c|}{ 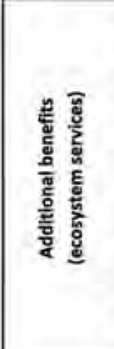 }} & $\begin{array}{l}\text { Provides wildlife, } \\
\text { habitat }\end{array}$ & + & & & & + & + & & + & + & + & + & & + \\
\hline & & Aesthetic quality & + & + & + & + & + & + & & + & + & + & + & & + \\
\hline & & $\begin{array}{l}\text { Stores runoff for } \\
\text { alternative use }\end{array}$ & & + & & & & & & & + & & & & \\
\hline & & $\begin{array}{l}\text { Provides additional } \\
\text { permeable surfaces }\end{array}$ & & & + & + & + & + & + & + & & & & & + \\
\hline & & Improves air quality & + & & + & + & + & + & & + & & + & + & & + \\
\hline & & $\begin{array}{l}\text { Provides educational } \\
\text { opportunities }\end{array}$ & + & & + & 't & & + & + & & & + & & & + \\
\hline
\end{tabular}

Figure 1: Elements of BGl and its functions and benefits (adapted from Collett et al., 2013).

the extent to which spatial planning and urban water management are linked because there is an evident need to provide sufficient urban space for implementing BGI. This link is highly recognized and promoted in international strategic documents (Table 2) and, to some extent, it can be noted in Slovenian legislation as well (Table 3). However, it can also be noted that Slovenia has not yet fully adopted international strategies in its national legislation, and so the link between spatial planning and urban water management is somehow weak. Only rainwater infiltration and green space planning are represented (Table 3). Moreover, there are (still) no valid standards or established practices in Slovenia for BGI planning and stormwater infiltration (Radinja et al., 2017).

BGI represents a way of coordinating spatial interventions (requirements and developments) and achieving some of the spatial planning objectives set out in the Spatial Planning Act (Sln. Zakon o urejanju prostora, 2017):

- Protecting space as a limited natural resource by ensuring better land use through multifunctionality;

- Providing quality living conditions and a healthy living environment by enhancing biodiversity;

- Contributing to promoting and protecting human health by improving air quality and reducing noise levels;

- Protecting the environment by reducing pollution (e.g., combined sewer overflows);

- Contributing to climate change adaptation;

- Creating conditions for reducing and preventing natural and other disasters by reducing the likelihood of flooding and by cooling the environment.

In Slovenia, spatial and urban planning have a long tradition of planning green areas and systems (e.g., Kučan, 1994), which is reflected both in spatial planning documents and in the space itself. This is also reflected in the layout of Slovenian cities and in studies of open public spaces in various Slovenian cities (e.g., Vertelj Nared, 2014; Volgemut, 2020). It can be concluded that in the majority of cases spatial planning in Slovenia addresses urban water management only indirectly by providing green areas or systems (Table 3). Nevertheless, these areas have a positive impact on urban drainage because they provide infiltration capacity and both smaller and slower surface runoff compared to paved surfaces. However, green areas have not (yet) been designed with an active function of stormwater retention and infiltration (i.e., they do not absorb surface runoff from adjacent paved surfaces), and so infiltration is provided passively or incidentally (Ministrstvo za okolje in prostor, 2020b). In terms of functionality, green areas should therefore be enhanced with BGI elements that provide additional ecosystem services, such as resilience to climate change, maintaining biodiversity, improving ecosystem functions, and providing other benefits to the population and the economy, particularly for public health, quality of life, and resource conservation. In this way, green systems in settlements will provide an extended set of environmental and ecological functions, thus forming green infrastructure as introduced in the proposal of the Spatial De- 
Table 2: Spatial planning and urban water management internationally.

\begin{tabular}{|c|c|}
\hline Spatial planning & Urban water \\
\hline 1. Urban Agenda for the EU: The Pact of Amsterdam (EC, 2016) & 1. Sustainable Development Goals (UN, 2015) \\
\hline $\begin{array}{l}\text { The priority topics include climate adaptation (including green infra- } \\
\text { structure solutions), sustainable land use, nature-based solutions, } \\
\text { and air quality. }\end{array}$ & $\begin{array}{l}\text { - Goal 6: Ensure availability and sustainable water management } \\
\text { and sanitation for all; } \\
\text { - Goal 11: Make cities and human settlements inclusive, safe, resil- } \\
\text { ient, and sustainable. }\end{array}$ \\
\hline 2. Nen & 2. Principles for Water Wise Cities (IWA, 2017) \\
\hline \multirow{5}{*}{$\begin{array}{l}\text { Two commitments for environmentally sustainable and resilient } \\
\text { urban development that are strongly related to water: } \\
\text { 72. We commit ourselves to long-term urban and territorial plan- } \\
\text { ning processes and spatial development practices that incorporate } \\
\text { integrated water-resource planning and management, considering } \\
\text { the urban-rural continuum at the local and territorial scales and in- } \\
\text { cluding the participation of relevant stakeholders and communities. } \\
73 \text {. We commit ourselves to promoting the conservation and sus- } \\
\text { tainable use of water by rehabilitating water resources within ur- } \\
\text { ban, peri-urban, and rural areas, reducing and treating wastewater, } \\
\text { minimizing water loss, promoting water reuse, and increasing water } \\
\text { storage, retention, and recharge, taking the water cycle into consid- } \\
\text { eration. }\end{array}$} & Level 2) Water-Sensitive Urban Design: \\
\hline & $\begin{array}{l}\text { - Planning and implementing urban designs that promote regener- } \\
\text { ative water services. }\end{array}$ \\
\hline & $\begin{array}{l}\text { - Designing urban spaces to reduce flood risks. Increasing resil- } \\
\text { ience to flood risks by developing improved drainage solutions } \\
\text { integrated within the urban infrastructure design to provide safe } \\
\text { flooding spaces. }\end{array}$ \\
\hline & $\begin{array}{l}\text { - Enhancing liveability by designing visible water areas in cities. } \\
\text { Roadside green infrastructure (rain gardens and bio-swales) and } \\
\text { major blue-green corridors as opportunities for social inclusion: } \\
\text { recreation, inclusive public spaces, economic development and } \\
\text { transportation, multi-purpose spaces, and infrastructure. }\end{array}$ \\
\hline & $\begin{array}{l}\text { - Modification and adaptation of urban materials (for roofs, wall } \\
\text { surfaces, roads, and urban furniture) to prevent the release of } \\
\text { pollutants when exposed to sun and rain. }\end{array}$ \\
\hline
\end{tabular}

Table 3: Spatial planning and urban water management in Slovenia.

\begin{tabular}{|c|c|}
\hline Spatial planning & Urban water \\
\hline $\begin{array}{l}\text { 1. Slovenian Spatial Development Strategy (Sln. Strategija prostorske- } \\
\text { ga razvoja Slovenije; Ministrstvo za okolje in prostor, 2004) }\end{array}$ & $\begin{array}{l}\text { 1. Slovenian Development Strategy } 2030 \text { (Sln. Strategijo razvoja Slo- } \\
\text { venije 2030; Služba Vlade Republike Slovenije za razvoj in evropsko } \\
\text { kohezijsko politiko, 2017) }\end{array}$ \\
\hline $\begin{array}{l}\text { Urban drainage is mentioned twice: } \\
\text { - The topic of urban development: "From a safety point of view, } \\
\text { settlements should have as much green space as possible to } \\
\text { compensate for large temperature extremes and to allow for the } \\
\text { gradual drainage of rainwater." } \\
\text { - The topic of wastewater and stormwater drainage and treatment: } \\
\text { "Stormwater and wastewater shall be discharged separately } \\
\text { where this is economically viable and technically feasible. Rainwa- } \\
\text { ter should be retained as long as possible at sites where it falls, } \\
\text { and surface runoff should be redirected into the nearest water } \\
\text { body." }\end{array}$ & $\begin{array}{l}\text { Goal 9: We will achieve sustainable natural resources management } \\
\text { by: } \\
\text { a) introducing an ecosystem-based approach to managing natural } \\
\text { resources and by moving past the sectoral way of thinking, such } \\
\text { as via the well-timed harmonization of national and cross-border } \\
\text { interests in mixed fields with regard to water, food, and energy } \\
\text { ecosystems, which should change and adapt in the future due to } \\
\text { the consequences of climate change; } \\
\text { b) effectively managing surface water and groundwater, coastal and } \\
\text { maritime resources, and achieving their good condition; }\end{array}$ \\
\hline $\begin{array}{l}\text { 2. Strategy for Protection and Development of Green Infrastructure } \\
\text { in the Ljubljana Urban Region (SIn. Strategija varstva in razvoja } \\
\text { zelene infrastrukture v Ljubljanski urbani regiji; RRA LUR, 2019) }\end{array}$ & 2. The Water Act \\
\hline
\end{tabular}

\section{Goal 1: Improved environmental status}

Particular attention should be paid to water management (infiltration, water retention, and flood protection) and to designing solutions that provide several functions at the same time (retention areas can be both attractive for leisure activities and have a positive impact on the microclimate).

\section{Goal 4: Climate change mitigation and adaptation}

It is important to manage both water-related extremes (water scarcity and flooding) and the connections with other activities, such as agriculture. Both extreme rainfall and temperatures can be mitigated with green infrastructure or spatial measures in urban areas.
The law stipulates that the protection of urban areas from the harmful effects of rainwater is the responsibility of the local government, which particularly includes measures to reduce surface runoff from urban areas and measures to limit the spills of wastewater and stormwater. Local government decrees usually regulate infiltration of rainwater whenever possible and permissible; however, if this is not possible, it is necessary to minimize the discharge of stormwater into the public sewerage system, either by retaining it or by reusing it (Odlok o odvajanju in čiščenju komunalne in padavinske odpadne vode v Mestni občini Ljubljana, 2018). 


\begin{tabular}{ll}
\hline Spatial planning & Urban water \\
\hline 3. The Spatial Planning Act & $\begin{array}{l}\text { 3. Decree on the Emission of Substances and Heat When Discharg- } \\
\text { ing Wastewater into Waters and the Public Sewage System (Sln. }\end{array}$ \\
$\begin{array}{l}\text { Uredba o emisiji snovi in toplote pri odvajanju odpadnih voda } v \text { vode } \\
\text { in javno kanalizacijo, 2012), Decree on the Emission of Substances in } \\
\text { the Discharge of Stormwater from Public Roads (SIn. Uredba o emisiji } \\
\text { snovi pri odvajanju padavinske vode z javnih cest, 2005) }\end{array}$ \\
\hline
\end{tabular}

The law defines green systems as a planned system for protecting and developing green spaces in urban areas and other green and manmade structures that are linked with them. The purpose of spatial planning (Article 2) is to achieve sustainable spatial development by comprehensively addressing, coordinating, and managing its social, environmental, and economic aspects to achieve spatial-planning objectives (e.g., to contribute to climate change and create conditions for reducing and preventing natural or other disasters).

4. Decree on the Spatial Order of Slovenia (SIn. Uredba o prostorskem redu Slovenije, 2004)

\footnotetext{
- Planning water-supply systems should rely on lower-quality water sources as much as possible when water is used as a source of process water, fire-fighting water, or other non-potable water (Article 52).

- Roof and terrace rainwater should be drained within the building plot by means of soakaways, soakaway trenches, or soakaway drainage pipes, in accordance with the environmental protection regulations.
}

The decree specifies under which conditions stormwater may (not) be discharged (indirectly) into groundwater, directly into inland water bodies, or into the sea. Restrictions are conditioned by the type of surface from which the stormwater originates, the water protection zones, or the type of aquifer the road crosses.
4. Decree on the Methodology for Determining Prices of Obligatory Municipal Public Services for Environmental Protection (SIn. Uredba o metodologiji za oblikovanje cen storitev obveznih občinskih gospodarskih javnih služb varstva okolja, 2012)

The decree stipulates that the cost of collecting and treating rainwater from roofs must be billed under a separate heading. This informs and motivates people to retain rainwater on their property and consequently reduces the flow of rainwater into the public sewerage system. velopment Strategy of Slovenia by 2050 (Ministrstvo za okolje in prostor, 2020a). The proposal defines green infrastructure at the regional level as green systems of regions and at the local level as green systems of settlements, thus paralleling it with the previously established planning of green systems.

Moreover, the Slovenian water legislation does not impose the use of BGI elements, but, at the same time, it does not prohibit their use either because it recommends the implementation of measures for surface runoff reduction, retention, or infiltration (Table 3). Therefore, taking into consideration all the characteristics of the local area and sectoral legislation, the implementation can start immediately, which can be proven by examples of successfully implemented BGI measures in Slovenia (Ramšak \& Oberžan, 2017; Klemen et al., 2020). Klemen et al. (2020) also found that expert studies for stormwater management measures are generally not provided during the preparation of spatial planning documents. This leads to the continued use of the existing water management concept, with only a few exceptions of the introduction of BGI in municipal spatial plans. Systemic measures, such as cooperation between institutions, strengthening strategic planning, and considering expert solutions, are also called for in the Strategy for the Protection and Development of Green Infrastructure in the Ljubljana Urban Region (RRA LUR, 2019). The strategy em- phasizes that "integrated and inclusive management are identified as key factors in sustaining the benefits and unlocking the potential benefits of green infrastructure" (RRA LUR, 2019: 33). At the same time, the strategy calls for green infrastructure planning beyond simple zoned land use.

In Slovenia, some cities have already moved toward implementing the target proposed by Brown (2009), a water-sensitive city, by introducing BGI (e.g., green roofs, mandatory stormwater retention, and infiltration). However, there is a lack of a comprehensive systemic approach (i.e., the flexible institutional framework mentioned above) because there is no adequate integration with other professionals (architects, urban planners, and spatial planners) involved in designing urban space. Below, we present cities that have already adopted and implemented such management strategies and approaches.

\section{Best-practice examples}

We have selected four examples of the systemic implementation of BGI at the city or national level from Denmark, the Netherlands, China, and the United States. Their geographical representation is intended to emphasize that the adoption of BGI in managing the urban water cycle is a global trend that 
points to future developments in this field. Common to all examples is the integration between water and spatial planning sectors for integrated BGI planning.

\subsection{Copenhagen: Adaptation to extreme rainfall events}

The Danish Meteorological Institute defines a precipitation event as extreme if more than $15 \mathrm{~mm}$ of precipitation falls in 30 minutes (Danish Meteorological Institute, 2019). In 2011, 136 $\mathrm{mm}$ of rain fell in 90 minutes in Copenhagen, which is statistically an event that occurs only once every two thousand years (Arnbjerg-Nielsen et al., 2015). As a result, the city suffered enormous damage. More than $30 \%$ of real estate owners in the city filed insurance claims, and the total damage exceeded $€ 800$ million (Arnbjerg-Nielsen et al., 2015). In response to this and some less intense rainfall events, the city adopted the Climate Adaptation Plan (City of Copenhagen, 2011) and then the Stormwater Management Plan (City of Copenhagen, 2012), which will cost about $€ 500$ million to implement.

Figure 2 shows the six-step approach to selecting the most appropriate solution for managing cloudbursts:

- First, the municipality identified and ranked areas within the city according to how vulnerable they are to cloudbursts, based on data and analysis of the current situation.

- In the second step, hydrological-hydraulic models that incorporated both surface runoff and sewerage systems were used to identify urban catchments and their risk of flooding.

- This was followed by assessment of the current state of flood damage, together with indirect costs and climate change impacts. The impacts are estimated at $€ 55$ to 80 million per year until 2110 .

- The next step was the creation of a BGI elements catalogue (i.e., the Cloudburst Toolkit) for cloudburst management (e.g., a green street, an urban creek, and a retention boulevard), which provided the basis for developing an ambitious adaptation plan for future cloudbursts. This was followed by architectural and landscape design, visualization of proposed solutions, and robustness testing.

- The fifth step involves all stakeholders, who then jointly design and create the proposed solutions. This type of design is an iterative process that leads to better solutions and ensures their quality.

- In the final step, the proposed alternative solutions are evaluated financially, and the most appropriate solution is selected based on a cost-benefit analysis.

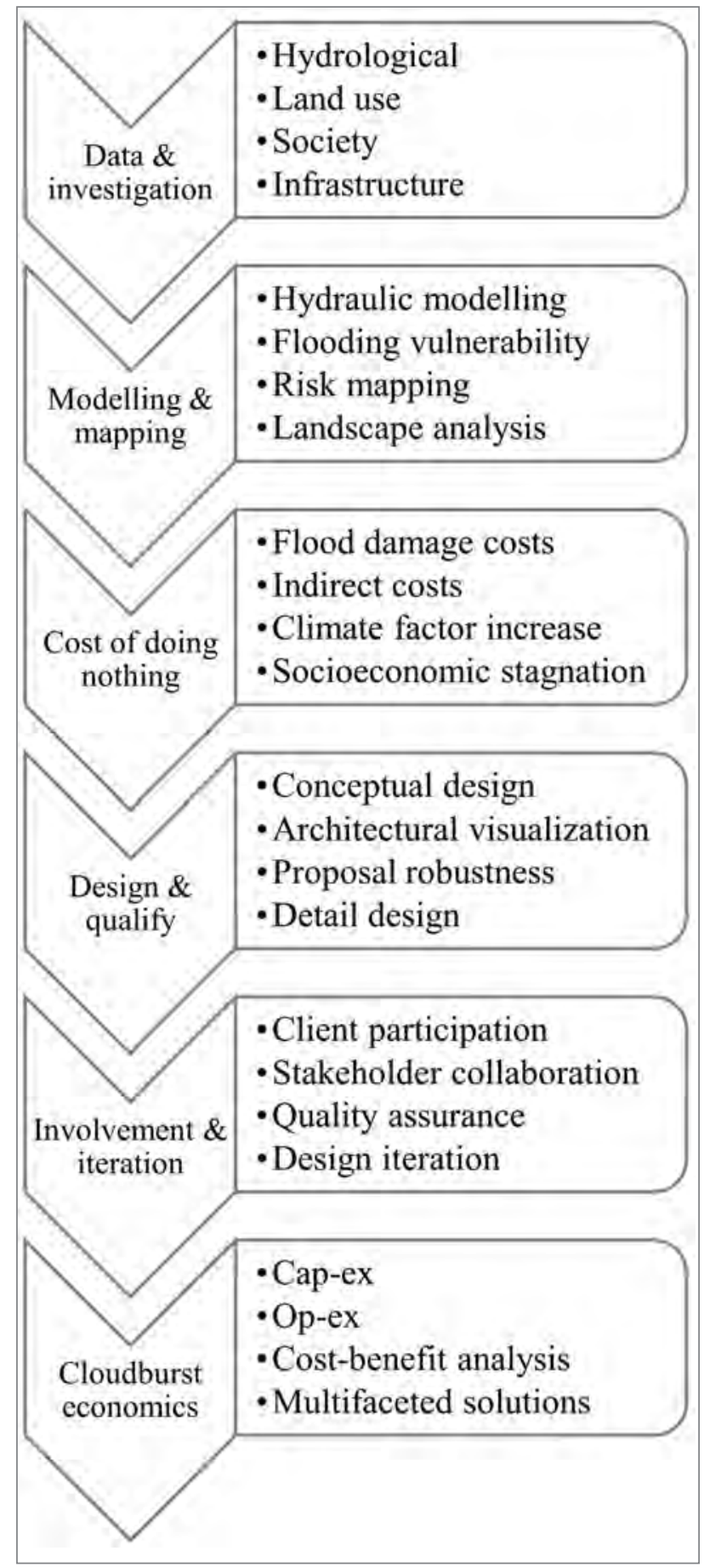

Figure 2: The Copenhagen approach to stormwater management (adapted from Ramboll, 2016).

\subsection{Rotterdam}

Rotterdam is Europe's largest port, located in the delta of the Rhine and Meuse rivers and threatened by water from four directions: the sea, the rivers, groundwater, and rainwater. Due to its extreme exposure and the ongoing impacts of climate 
change, the city has adopted a climate-change adaptation strategy (Rotterdam Climate Initiative, 2013). The strategy is based on an approach that combines overcoming water-related issues with opportunities for urban transformation and socioeconomic development. Action planning is based on the results of hydrological-hydraulic models that determine the risk of flooding of specific areas within the city, whether from the sea, rivers, or extreme rainfall events. For rainfall, the main measure envisaged is BGI, which is designed to retain stormwater at the site and slow its runoff. In designing a water-resilient city, special attention is paid to every individual site, involving water committees, urban planners, a municipal administration, and other stakeholders that help create the measures. Public awareness and active participation are promoted through active and targeted communication.

\subsection{Chinese sponge cities}

In response to the problems in the urban water cycle (e.g., flooding and pollution of water bodies) that were caused by the rapid urbanisation of Chinese cities, the Chinese government has developed the concept of sponge cities. In 2014, thirty cities across the country, including megacities, such as Beijing, Shanghai, Tianjin, and Shenzhen, were included to serve as pilot areas from which best practices and regulatory frameworks can be transferred to other cities (Chan et al., 2018). The concept of sponge cities is based on BGI and the implementation of six processes in urban stormwater management: infiltration, stagnation, storage, purification, utilisation, and discharge (Liu et al., 2017). The activities that are introducing the concept in cities mainly focus on 1) the construction of sponge buildings (e.g., green roofs and rain gardens), 2) the construction of sponge streets, sidewalks, and squares using permeable materials, 3 ) the construction of sponge parks and green areas (e.g., rain gardens, sunken green fields, and artificial wetlands), 4) the protection and remediation of natural water bodies (e.g., management of natural waterways, increasing wetlands, etc.), $5)$ improving the connectivity of urban water systems to allow their continuity, 6) upgrading existing drainage systems to provide flood protection and discharge of excess water, and 7) constructing separate systems for stormwater and wastewater (Liu et al., 2017). The results of the design and performance of BGIs allow the transfer of knowledge from the pilot cities to other cities, which can follow with fast implementation and better planning of BGI (Yin et al., 2021).

\subsection{The United States: The BGI concept for wastewater management}

Combined sewer overflows are elements in a combined sewerage system that discharge excess stormwater and sanitary wastewater directly into water bodies during rainfall events, therefore protecting the sewerage system and the city from flooding. At the same time, they pose an environmental hazard because, although diluted, they discharge untreated wastewater into water bodies. After a requirement from the U.S. Environmental Protection Agency to establish a long-term plan for the operation of combined sewer overflows (United States Congress, 2002), Philadelphia decided on an alternative approach. Consequently, the decision was made to implement BGI throughout the city, instead of building additional grey infrastructure (e.g., underground storage tanks or collectors). The result is a twenty-five-year plan called Green City, Clean Waters (Philadelphia Water Department, 2011). It was calculated that after forty-five years the plan would return more benefits and added value to the city than the investment. Through structured information and awareness raising of all stakeholders, the plan has resulted in residents now perceiving city streets differently. They now recognize the possibilities for transformation of previously impervious surfaces into green, lush areas that retain, treat, and control stormwater runoff.

The introduction of the plan was followed by the creation of a comprehensive guide that makes it easy for potential developers to become familiar with all the necessary requirements that a project must meet to adequately address water management within the development area (Philadelphia Water Department, 2014). The city is divided into sub-areas based on hydrological-hydraulic characteristics (e.g., floodplain areas and type of sewerage system), which allow developers to determine the general water management requirements (e.g., 100\% infiltration, and partial retention and treatment of stormwater) by using the guide.

Despite the positive progress, researchers have found that pursuing only one objective in BGI implementation (i.e., largescale water retention) can lead to systematic implementation of a limited set of BGI measures that provide only limited benefits (Spahr et al., 2020). Therefore, Spahr (2020) concluded that, if cities want to achieve the ecosystem services provided by plants (i.e., air purification, reduction of noise and the heat island effect, a pleasant appearance, and public health), they will need to increase the use of this type of BGI.

\subsection{Comparison of best practices}

In both European cases, the main cause for the paradigm shift in urban water management was prevailing climate change impacts and the prediction of more frequent and intense rainfall events that will cause floods. On the other hand, the Chinese and American cases were triggered by the quality of water bodies and the negative impact of urbanization on them. Common to all the examples is the recognition that grey infrastructure 
Table 4: Overview of successful foreign practices.

\begin{tabular}{|c|c|c|c|c|}
\hline & Copenhagen & Rotterdam & China, thirty pilot cities & Philadelphia \\
\hline Cause & Floods, climate change & Floods, climate change & Environmental pollution, floods & $\begin{array}{l}\text { Environmental pollution: } \\
\text { combined sewerage } \\
\text { overflows }\end{array}$ \\
\hline $\begin{array}{l}\text { Name and year } \\
\text { of programme } \\
\text { adoption }\end{array}$ & $\begin{array}{l}\text { The Copenhagen Climate } \\
\text { Adaptation Plan, 2011; } \\
\text { The Cloudburst Manage- } \\
\text { ment Plan, } 2012\end{array}$ & $\begin{array}{l}\text { The Rotterdam Climate } \\
\text { Change Adaptation Strategy, } \\
2013\end{array}$ & $\begin{array}{l}\text { The Sponge City Programme, } \\
2014\end{array}$ & $\begin{array}{l}\text { Green City, Clean Waters, } \\
2011\end{array}$ \\
\hline Goal & $\begin{array}{l}\text { 1) Preventing inflow of } \\
\text { surface runoff into the } \\
\text { sewerage system from } \\
\text { more than one-third of } \\
\text { the non-impervious area. } \\
\text { 2) When a cloudburst } \\
\text { with a hundred-year } \\
\text { return period occurs, a } \\
\text { maximum of } 10 \mathrm{~cm} \text { of } \\
\text { surface water (prevention } \\
\text { of flooding) }\end{array}$ & $\begin{array}{l}\text { Complete climate change } \\
\text { resilience of the city by } 2025\end{array}$ & $\begin{array}{l}\text { By } 2030 \text {, at least } 70 \% \text { of pre- } \\
\text { cipitation will be infiltrated or } \\
\text { reused on } 80 \% \text { of urban areas. }\end{array}$ & $\begin{array}{l}\text { The prevention of inflow } \\
\text { of surface runoff to sew- } \\
\text { erage system from more } \\
\text { than one-third of the } \\
\text { non-impervious area in } \\
\text { the next twenty-five years }\end{array}$ \\
\hline $\begin{array}{l}\text { Developed } \\
\text { guidelines and } \\
\text { planning tools } \\
\text { in response to } \\
\text { detected prob- } \\
\text { lems }\end{array}$ & $\begin{array}{l}\text { 1) The Copenhagen } \\
\text { Cloudburst Formula } \\
\text { (guidelines for strategic } \\
\text { planning of BGI); } \\
\text { 2) The Copenhagen } \\
\text { Cloudburst Toolkit (cata- } \\
\text { logue of BGI elements) }\end{array}$ & $\begin{array}{l}\text { 1) The Interactive Climate } \\
\text { Atlas (the atlas makes it } \\
\text { possible to compare the } \\
\text { consequences of various } \\
\text { climate scenarios for a given } \\
\text { location); } \\
\text { 2) The Climate Adaptation } \\
\text { Barometer (the tool can be } \\
\text { used to structure the climate } \\
\text { change adaptation strategy } \\
\text { and to keep track of the } \\
\text { process); } \\
\text { 3) The Climate Adaptation } \\
\text { Toolbox (the toolbox pro- } \\
\text { vides an overview of poten- } \\
\text { tial adaptation measures for } \\
\text { various spatial scale levels } \\
\text { and aims) }\end{array}$ & $\begin{array}{l}\text { 1) The Code for Design of Ur- } \\
\text { ban Green Space (the code is } \\
\text { harmonized with guidelines for } \\
\text { sponge cities, with emphasis on } \\
\text { an integrated approach for plan- } \\
\text { ning urban green areas); } \\
\text { 2) The Code for Design of Urban } \\
\text { Road Engineering (the code is } \\
\text { harmonized with guidelines for } \\
\text { sponge cities; it includes a chap- } \\
\text { ter on BGI); } \\
\text { 3)The Assessment Standard for } \\
\text { Sponge City Effects (technical } \\
\text { standards for assessment of } \\
\text { sponge city effects) }\end{array}$ & $\begin{array}{l}\text { 1) The Stormwater } \\
\text { Management Guidance } \\
\text { Manual (guidelines for } \\
\text { planning BGl, a catalogue } \\
\text { of BGl elements); } \\
\text { 2) A Homeowner's Guide } \\
\text { to Stormwater Manage- } \\
\text { ment (practical guidelines } \\
\text { for homeowners on how } \\
\text { to manage stormwater) }\end{array}$ \\
\hline
\end{tabular}

can neither provide solutions to all the emerging problems nor deliver ecosystem benefits. The cities presented have identified multifunctional BGIs as an appropriate solution, which is in line with the water-sensitive city approach (Table 1). Furthermore, BGI has been successfully integrated into the cities' strategic documents, which also include well-defined objectives (Table 4). It is important that after adaptation of strategies public funds also be allocated to achieving the set objectives. The success of the cities presented in adopting BGI is also conditioned by the development of professional guidelines and planning tools that provide support to city planners. Moreover, common to all the cases presented is the involvement of the water sector in spatial planning. Water engineers use hydrological-hydraulic models to 1) identify (current and potential) critical points of flood risk in urban areas and assesses the impact of individual BGI scenarios on the urban water cycle through simulations, and 2) assesses the quality impact of BGI on urban surface runoff and consequently on the ecological status of the receiving water bodies.

\section{Conclusion}

The management of urban space and its associated elements lies in the domain of various disciplines. This article has presented the current state and challenges of urban water management in Slovenia and in some cities globally. The much-needed link between water management and urban planning is encouraged in international strategic documents; however, this link has not been sufficiently adopted in Slovenian national legislation. Thus, a predominantly sectoral approach in water management and urban planning is practiced in Slovenian cities. 
Based on the examples of urban water-management best practices presented, it can be concluded that in some cities the systemic introduction of BGI has become an established approach rather than an alternative one in urban planning. This is not the case for Slovenian cities yet, but there is a great potential because Slovenian cities have sufficient well-distributed green areas (public and private), which is a consequence of spatial planning practices already established (Ministrstvo za okolje in prostor, 2020b). Currently green areas are not planned according to BGI principles, and so their multifunctionality, which could be achieved by absorbing surface runoff from surrounding paved areas, is not (sufficiently) utilized. Therefore, a great potential remains for green areas in cities that could provide additional above- or below-ground retention areas to relieve the pressure on the sewerage system and keep precipitation within the natural water cycle. The best-practice examples presented show that the implementation of many decentralized measures can significantly improve the water balance of the sewerage system and reduce the likelihood of their overflow and thus flooding of urban areas.

The best-practice examples analysed show that interdisciplinary cooperation between different disciplines and cross-sectoral coordination at the planning and operational levels are key in BGI planning. From the perspective of the water sector, which primarily manages the urban water cycle, it is essential that spatial planning include expert studies for the sustainable management of water resources and adaptation to climate change. Furthermore, creation of guidelines and technical manuals for planning and dimensioning BGI is also of great importance for the planning and implementation phase.

It can be concluded that, despite individual efforts, in Slovenia BGI is still not recognized as an effective concept for comprehensive management of the urban water cycle. Such management requires a holistic approach, which encompasses modelling, planning, and dimensioning of the most appropriate measures. Nevertheless, these efforts indicate a growing awareness of the importance of BGI and the need for its systematic integration into the legislative framework to ensure adequate involvement of key stakeholders, interdisciplinary cooperation between disciplines, and cross-sectoral coordination for comprehensive urban water management.

Matej Radinja, University of Ljubljana, Faculty of Civil and Geodetic Engineering, Department of Environmental Civil Engineering, Ljubljana, Slovenia

E-mail: matej.radinja@fgg.uni-lj.si

Nataša Atanasova, University of Ljubljana, Faculty of Civil and Geodetic Engineering, Department of Environmental Civil Engineering, Ljubljana, Slovenia

E-mail: natasa.atanasova@fgg.uni-lj.si
Alma Zavodnik Lamovšek, University of Ljubljana, Faculty of Civil and Geodetic Engineering, Chair of Spatial Planning, Ljubljana, Slovenia

E-mail:alma.zavodnik@fgg.uni-lj.si

\section{Acknowledgements}

This study was supported by the project Closing Material Flows with Green Technologies (no. J2-8162) and the research programme no. P2-0180, funded at the national level by the Slovenian Research Agency.

\section{References}

Agudelo-Vera, C. M., Mels, A. R., Keesman, K. J. \& Rijnaarts, H. H. M. M. (2011) Resource management as a key factor for sustainable urban planning. Journal of Environmental Management, 92, pp. 2295-2303. DOI: 10.1016/j.jenvman.2011.05.016

Arnbjerg-Nielsen, K., Leonardsen, L. \& Madsen, H. (2015) Evaluating adaptation options for urban flooding based on new high-end emission scenario regional climate model simulations. Climate Research, 64 pp. 73-84. DOI: 10.3354/cr01299

Bacchin, T. K., Ashley, R., Sijmons, D., Zevenbergen, C. \& Van Timmeren, A. (2014) Green-blue multifunctional infrastructure: An urban landscape system design new approach. Conference proceedings: 13th Int. Conf. Urban Drainage. Sarawak, Malaysia. DOI: 10.13140/2.1.2061.5049

Brown, R. R., Keath, N. \& Wong, T. H. F. (2009) Urban water management in cities: historical, current and future regimes. Water Science and Technology, 59, pp. 847-855. DOI: 10.2166/wst.2009.029

Butler, D., Davies, J., James Digman, C., Makropoulos, C. \& Davies, J. (2018) Urban drainage. 4th ed. Boca Raton, FL, CRC Press. DOI: 10.1201/9781351174305

Chan, F. K. S., Griffiths, J. A., Higgitt, D., Xu, S., Zhu, F., Tang, Y. T., et al. (2018) "Sponge city" in China - A breakthrough of planning and flood risk management in the urban context. Land Use Policy, 76, pp. 772778. DOI: 10.1016/j.landusepol.2018.03.005

Chow, J. F., Savić, D., Fortune, D., Kapelan, Z. \& Mebrate, N. (2014) Using a systematic, multi-criteria decision support framework to evaluate sustainable drainage designs. Procedia Engineering, 70, pp. 343-352. DOI: 10.1016/j.proeng.2014.02.039

City of Copenhagen (2011) Copenhagen climate adaptation plan. Available at: https://en.klimatilpasning.dk/media/568851/copenhagen_adaption_plan.pdf (accessed 12 Apr. 2019).

City of Copenhagen (2012) The city of Copenhagen cloudburst management plan 2012. Available at: https://en.klimatilpasning.dk/media/665626/cph_-_cloudburst_management_plan.pdf (accessed 12 Apr. 2019).

Collett, B., McCown, K. \& Wall, S. (2013) Low impact development: opportunities for the PlanET region. Available at: https://issuu.com/utkcoad/ docs/2013_0807_-_lid_opportunities_for_t (accessed 19 Sept. 2019).

Danish Meteorological Institute (2019) What to expect when DMI alerts clouds? Available at: https://www.dmi.dk/nyheder/2019/hvad-skal-duforvente-nar-dmi-varsler-skybrud/ (accessed 9 Jun. 2019).

Directive 2000/60/EC of the European Parliament and of the Council of 23 October 2000 establishing a framework for community action in the field of water policy. Official Journal L 327, 22/12/2000 P. 0001 0073. 
Dolinar, M., Vertačnik, G., Bertalanič, R., Dvoršek, D., Nadbath, M., Gartner, D., et al. (2014) Podnebne spremembe v Sloveniji - Podnebne podlage za pripravo ocene tveganj in priložnosti, ki jih podnebne spremembe prinašajo za Slovenijo 1. poročilo (različica 2). Ljubljana, Agencija RS za okolje.

European Commission (2020) Nature-based solutions. Available at: https://ec.europa.eu/research/environment/index.cfm?pg=nbs (accessed 17 Jul. 2020).

Fletcher, T. D., Shuster, W., Hunt, W. F., Ashley, R., Butler, D., Arthur, S., et al. (2015) SUDS, LID, BMPs, WSUD and more - The evolution and application of terminology surrounding urban drainage. Urban Water Journal, 12, pp. 525-542. DOI: 10.1080/1573062X.2014.916314

Globevnik, L. \& Simoneti, M. (2020) Obvladovanje vode v mestih - naša skupna skrb. Slovenski vodar, 30, pp. 11-14.

Hung, Y. Y., Aquino, G. \& Waldheim, C. (2012) Landscape infrastructure: Case studies by SWA. Basel, Birkhäuser. DOI: 10.1515/9783034611541

International Water Association (2017) Principles for water wise cities. Available at: https://iwa-network.org/wp-content/uploads/2016/10/ IWA_Brochure_Water_Wise_Communities_SCREEN-1.pdf (accessed 12 Mar. 2019).

Klemen, K., Pergar, P., Futar, M., Bevc Šekoranja, B. \& Konda, K. (2020) Problematika načrtovanja sonaravnih ukrepov za celovito upravljanje padavinskih voda na urbanih območjih. Gradbeni vestnik, 69, pp. 61-92.

Krajnc, U. (2019) Podnebne spremembe in poplavna ogroženost urbanih območij z lastnimi padavinskimi vodami. Gradbeni vestnik, 68, pp. 109-132.

Kučan, A. (1994) Zeleni sistem Ljubljane. Urbani izziv, 26/27, pp. 65-72. DOI: 10.5379/urbani-izziv-en-1994-26-27-009

Lamond, J., Everett, G. (2019) Sustainable blue-green infrastructure: A social practice approach to understanding community preferences and stewardship. Landscape and Urban Planning, 191, 103639. DOI: 10.1016/j.landurbplan.2019.103639

Langergraber, G., Pucher, B., Simperler, L., Kisser, J., Katsou, E., Buehler, D., et al. (2020) Implementing nature-based solutions for creating a resourceful circular city. Blue-Green Systems, 2, pp. 173-185. DOI: $10.2166 /$ bgs.2020.933

Liao, K-H., Deng, S. \& Tan, P. (2017) Blue-green infrastructure: New frontier for sustainable urban stormwater management. In: Tan, P. \& Jim, C. (eds.) Greening cities. Forms and Functions, pp. 203-226. Singapore, Springer. DOI: 10.1007/978-981-10-4113-6_10

Liu, H., Jia, Y. \& Niu, C. (2017) "Sponge city" concept helps solve China's urban water problems. Environmental Earth Sciences, 76, 473. DOI: $10.1007 / \mathrm{s} 12665-017-6652-3$

Ministrstvo za okolje in prostor (2004) Strategija prostorskega razvoja Slovenije. Ljubljana.

Ministrstvo za okolje in prostor (2020a) Strategija prostorskega razvoja Slovenije 2050: Osnutek dokumenta v javni razpravi. Ljubljana. Available at: https://www.gov.si/assets/ministrstva/MOP/Dokumenti/Prostorski-razvoj/SPRS/SPRS-2050_gradivo-za-javno-razpravo.pdf (accessed 20 Jan. 2020).

Ministrstvo za okolje in prostor (2020b) Zeleni sistem v mestih in naseljih. Ljubljana. Available at: https: //www.gov.si/assets/ministrstva/MOP/Dokumenti/Prostorski-red/zeleni-sistem.pdf (accessed 20 Jan. 2021).

Morales-Torres, A., Escuder-Bueno, I., Andrés-Doménech, I., Perales-Momparler, S. (2016) Decision support tool for energy-efficient, sustainable and integrated urban stormwater management. Environmental Modelling \& Software, 84, pp. 518-528.

DOI: 10.1016/j.envsoft.2016.07.019
Odlok o odvajanju in čiščenju komunalne in padavinske odpadne vode v Mestni občini Ljubljana. Uradni list Republike Slovenije, no. 9/2018. Ljubljana.

Panjan, J. (2005) Osnove zdravstevno hidrotehnične infrastrukture. Ljubljana, Univerza v Ljubljani, Fakulteta za gradbeništvo in geodezijo.

Philadelphia Water Department (2011) Green city, clean waters - implementation and adaptive management plan. Philadelphia.

Philadelphia Water Department (2014) Stormwater management guidance manual. Philadelphia. Philadelphia.

Radinja, M., Banovec, P. \& Atanasova, N. (2017) Standardi na področju razpršenih ukrepov zadrževanja in ponikanja padavinskih voda na urbanih območjih. Ekolist, 14, pp. 43-46.

Radinja, M., Comas, J., Corominas, L. \& Atanasova, N. (2019) Assessing stormwater control measures using modelling and a multi-criteria approach. Journal of Environmental Management, 243, pp. 257-268. DOI: 10.1016/j.jenvman.2019.04.102

Ramboll, (2016) Copenhagen cloudburst plans. Available at: https:// acwi.gov/climate_wkg/minutes/Copenhagen_Cloudburst_Ramboll_ April_20_2016 (4).pdf (accessed 9 Aug. 2019).

Ramšak, V. \& Oberžan, T. (2017) Problematika odvodnje padavinskih voda $z$ urbaniziranih površin. In: Vuk, T. (ed.) Beton in ekstremne podnebne razmere. Ljubljana, Združenje za beton.

Ravnikar, Ž. \& Goličnik Marušić, B. (2019) Na naravi temelječe rešitve: predstavitev projekta Connecting nature. Urbani izziv, 30(1), pp. 144146.

RRA LUR (2019) Strategija varstva in razvoja zelene infrastrukture $v$ Ljubljanski urbani regiji. Ljubljana. Available at: https://rralur.si/wp-content/ uploads/2020/05/Strategija-ZILUR_2019.pdf (accessed 19 Jan. 2021).

Rotterdam Climate Initiative (2013) Rotterdam: Climate change adaptation strategy. Available at: http://www.urbanisten.nl/wp/wp-content/ uploads/UB_RAS_EN_Ir.pdf (accessed 20 Jan. 2021).

Serrao-Neumann, S., Renouf, M., Kenway, S. J. \& Low Choy, D. (2017) Connecting land-use and water planning: Prospects for an urban water metabolism approach. Cities, 60(A), pp. 13-27.

DOI: 10.1016/j.cities.2016.07.003

Služba Vlade Republike Slovenije za razvoj in evropsko kohezijsko politiko (2017) Strategija razvoja Slovenije 2030. Ljubljana, SVRK.

Spahr, K. M., Bell, C. D., McCray, J. E. \& Hogue, T. S. (2020) Greening up stormwater infrastructure: Measuring vegetation to establish context and promote cobenefits in a diverse set of US cities. Urban Forestry \& Urban Greening, 48, 126548. DOI: 10.1016/j.ufug.2019.126548

United Nations (2016) New urban agenda - Quito declaration on sustainable cities and human settlements for all. New York. Available at: https:// habitat3.org/the-new-urban-agenda/ (accessed 9 Aug. 2019).

United Nations (2015) Transforming our world: the 2030 agenda for sustainable development. Available at: https://www.un.org/ga/search/ view_doc.asp?symbol=A/RES/70/1\&Lang=E (accessed 20 Jan. 2021).

United States Congress (2002) Federal water pollution control act. Available at: https://www.epa.gov/sites/production/files/2017-08/documents/ federal-water-pollution-control-act-508full.pdf (accessed 12 Apr. 2019).

Uredba o emisiji snovi in toplote pri odvajanju odpadnih voda v vode in javno kanalizacijo. Uradni list Republike Slovenije, nos. 64/2012, 64/2014, 98/2015. Ljubljana.

Uredba o emisiji snovi pri odvajanju padavinske vode $z$ javnih cest. Uradni list Republike Slovenije, no. 47/2005. Ljubljana. 
Uredba o metodologiji za oblikovanje cen storitev obveznih občinskih gospodarskih javnih služb varstva okolja. Uradni list Republike Slovenije, nos. 87/2012, 109/2012, 76/2017. Ljubljana.

Uredba o prostorskem redu Slovenije. Uradni list Republike Slovenije, nos. 122/2004, 33/2007. Ljubljana.

Vertelj Nared, P. (2014) Vloga javnega prostora kot podpora urbanemu razvoju na primeru majhnih mest v Sloveniji. Doctoral dissertation. Ljubljana, University of Ljubljana, Faculty of Civil and Geodetic Engineering.

Volgemut, M. (2020) Vpliv lokacije storitev splošnega pomena na razvoj odprtega javnega prostora na primeru majhnih mest v Sloveniji. Doctoral dissertation. Ljubljana, University of Ljubljana, Faculty of Civil and Geodetic Engineering.

Woods Ballard, B., Wilson, S., Udale-Clarke, H., Illman, S., Scott, T., Ashley, R., et al. (2015) The SUDS manual. London, Construction Industry Research and Information Association. Available at: https://www. susdrain.org/resources/SuDS_Manual.html (accessed 20 Jan. 2021).

Yin, D., Chen, Y., Jia, H., Wang, Q., Chen, Z., Xu, C., et al. (2021) Sponge city practice in China: A review of construction, assessment, operational and maintenance. Journal of Cleaner Production, 280(2921), 124963. DOI: 10.1016/j.jclepro.2020.124963

Zakon o urejanju prostora. Uradni list Republike Slovenije, no. 61/2017. Ljubljana.

Zakon o vodah. Uradni list Republike Slovenije, nos. 67/02, 2/04 -

ZZdrl-A, 41/04 - ZVO-1, 57/08, 57/12, 100/13, 40/14, 56/15. Ljubljana. 